\title{
A CASE OF JUVENILE AMAUROTIC IDIOCY WITH DISTURBANCES IN WATER-SALT METABOLISM
}

\section{E. CUNNINGHAM DAX}

JUVENILE amaurotic idiocy was first described by Batten in 1903 . It is also known as Batten-Mayou's, Spielmeyer-Vogt's or Oatman's Disease. Cerebro-macular or cerebro-retinal degeneration are other names given to the same condition, but they are inadequate descriptions, for it is one of the lipoidoses and histologically related to Tay-Sachs' disease.

The course followed by the affection is quite characteristic. There is failing sight in a child of five to eight years, which rapidly progresses to blindness. Within two or three years mental deterioration begins which ultimately results in a deep dementia, although the child was previously of normal intelligence. Epilepsy usually occurs about this time and in the later stages other neurological signs can be elicited. In particular, there is weakness, an unsteady gait, contractures and perhaps accompanying extrapyramidal signs or more rarely evidence of upper motor neurone involvement. Death usually occurs before the twentieth year.

Zondek and Koehler (1932) regarded the eye changes in juvenile amaurotic idiocy as an atypical form of pigmentary degeneration of the retina. They gave evidence, based on the findings of Velhagen (1932), that there may be diencephalic abnormalities associated with this condition, and also showed that hypophysohypothalamic disturbances occurred in apparently simple cases of retinitis pigmentosa, as well as the Laurence-Moon-Biedl syndrome. Although cerebro-retinal degeneration is not usually regarded as being related to retinitis pigmentosa in view of the different pathology of the two conditions, there are certain points of resemblance. Both are considered to have an heredodegenerative origin in which consanguinity is of frequent occurrence. There are pigmentary retinal changes in each, though in cerebro-retinal degeneration the central areas are affected earlier and more extensively than the periphery. In addition, both progress to blindness.

In recent years there has been an increasing amount of evidence produced to show an association between retinitis pigmentosa and diencephalic disturbances. A case of cerebro-retinal degeneration showing metabolic abnormalities attributable to the hypophysohypothalamic system is therefore of interest. 
Case Record.

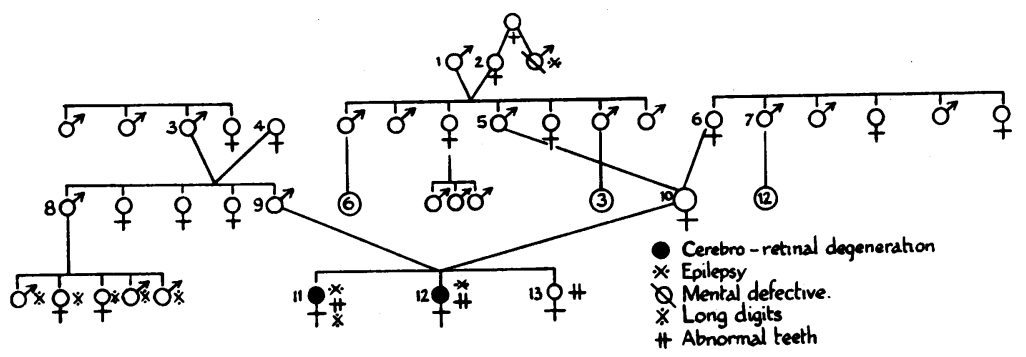

(1) Died, aged 36 years, cause unknown. (2) Died, aged 67 years, heart failure. She had a step-brother who was an epileptic mental defective. (3) Died, aged 71 years, carcinoma of larynx. (4) Died, aged 65 years, heart failure. (5) Died, aged 35 years, " poisoning." (6) Died, aged 35 years, carcinoma. (7) He has twelve normal children. (8) Has five children all of whom have long fingers. (9) The father, healthy and intelligent. (10) In poor health following a hysterectomy. Inclined to be neurotic. The father and mother were not related before marriage. (11) The patient. (12) A sister three years younger than the patient and very similar to her. Her sight began to fail at the age of eight, and recently it has become very bad. When she was thirteen she developed epilepsy, the fits being similar to her sister's. Her periods are regular and she has no polyuria or polydipsia. Her extremities are said to be of normal length; she was obese but has recently lost weight. She perspires excessively. Her speech is very like the patient's, she chatters, stutters and is difficult to understand. Her teeth are also small. (13) Four years younger than the patient. Teeth small and she perspires freely. Her periods are regular, her skeleton is well proportioned and her speech and sight are normal.

Past history.-Forceps were used at her birth, but without any complications. She walked and talked at the normal ages, and her teeth erupted early. She had measles, whooping cough, and frequent attacks of tonsillitis as a child.

She went to school when five, but at the age of eight her sight began to fail and she was sent into hospital. Later she went to a school for the blind where she stayed until fits started at the age of thirteen. She next went to an epileptic colony, a neurological hospital and then came to Leavesden Hospital. She was normal at school and learned to read, write and play the piano by ear. She learned Braille, became a Girl Guide and was said to have a remarkably good memory for historical dates. When aged eigheeen she became paranoidal, hallucinated for sight, screamed at night, chattered frequently, lost control of her temper and sat about brooding. Her speech became indistinct at this time. 


\section{Present Condition}

Mental.-She is not very easy of approach, and will talk more freely at some times than others. It is rather difficult to follow her, for her answers to questions are interspersed with reflections of her own and she repeats sentences over and over again. Nevertheless her general knowledge is good, and she can give an account of her auditory and visual hallucinations. She chatters particularly at night, and is then rather restless. The nursing staff do not find her easy to manage, though she is more resistive than aggressive. She is clean in her habits.

Physical, Eyes.-Both discs are atrophic and clear cut. The vessels are fine but can be followed all over the retinae. There is a small amount of fine spidery pigment all over the central areas of the retinae extending to the equatorial regions. The macular pigmentation is more dense than that elsewhere in the fundi. She is quite blind without appreciation of light. There is a marked degree of nasal corectopia, the irides have a green outer margin and more medially a green speckling on a yellow brown background. There is little difference in colour between them. There is a slight divergent strabismus and a vertical nystagmus more marked in the right eye than the left. She is myopic, the right fundus is focused with a-6.0D lens and the left with a-4.0D.

General.-Her skin is smooth and her hair soft and brown. The ears are small and the lobules adherent. The teeth are good but very small. The wisdoms have not erupted. There is some dilatation of the veins at the frenum of the tongue. She was fairly well covered with fat on admission but is rapidly growing thin. The left nipple is much smaller than the right, but the areola is larger and less pigmented.

The digits are all very long, the second toes are longer than the first. The hands and feet are thin and long as are the limbs, suggesting a mild degree of arachnodactyly (the condition of the feet and legs is well shown in the photograph). The extended forearms can be approximated and there is a slight lower dorsal kyphosis. There is no winging of the scapulae, the ligaments are lax. Pulse 70-90/min. Blood pressure 100/50. Accentuated apical second sound and a systolic murmur best heard here but not conducted. Thyroid normal and no abnormality was found in the lungs or abdomen.

Pupils equal, dilate evenly with atropine, and do not react to light. There is vertical nystagmus and divergent strabismus. The left lower face moves before the right. The speech has a definite explosive quality. There is some verbigeration and perseveration.

The abdominal reflexes are very brisk, the remainder are sluggish. The plantar responses are both flexor and there is no 


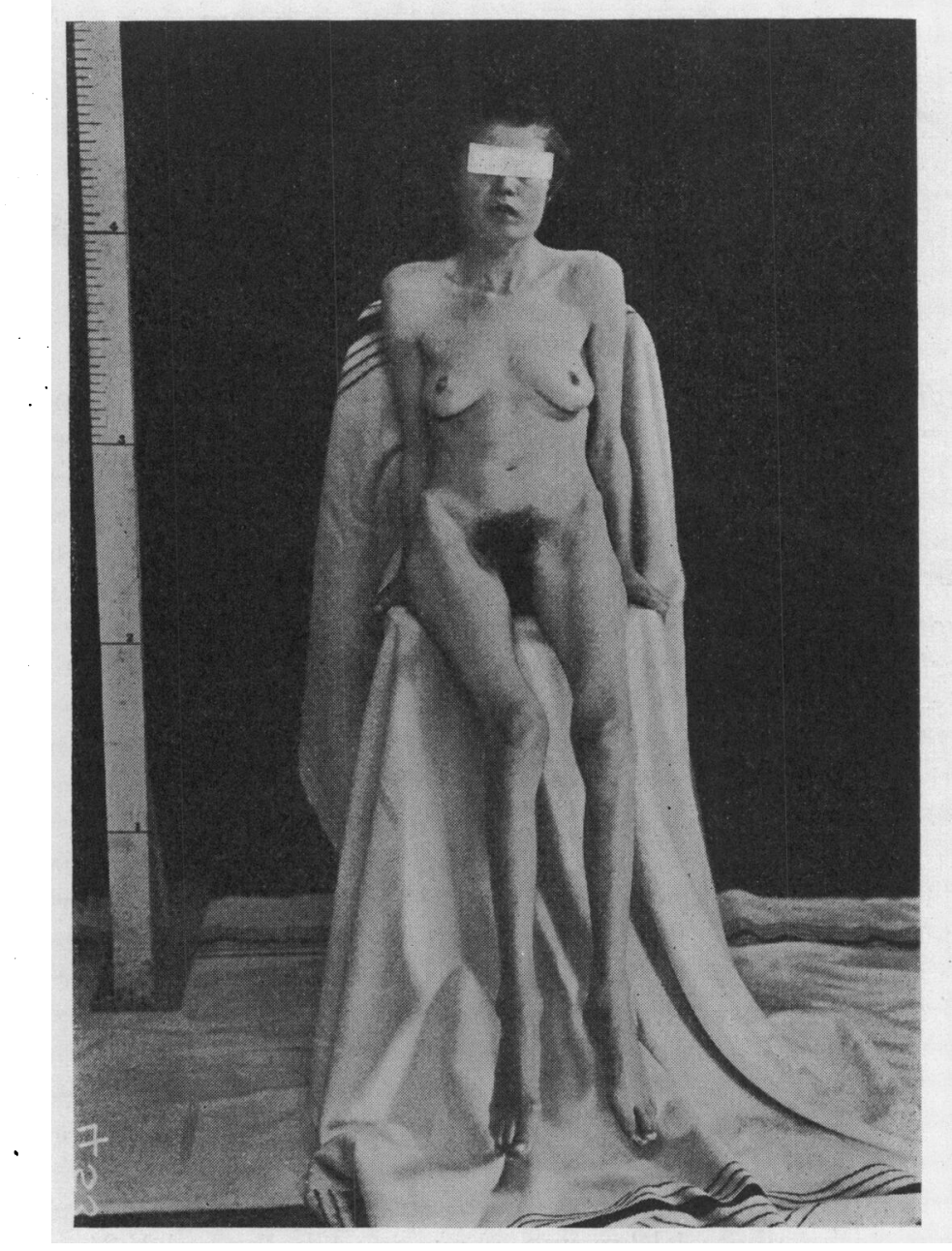

clonus. No intention tremor or dysdiadochokinesis. Her arms are held steadily in front. Sensation other than that of pain (which is normal) cannot be tested.

She cannot stand or walk without assistance. She raises her feet rather high from the ground but she does not appear to be ataxic.

For some time she has complained of much headache which is referred to the back of her head. Sleep is normal.

Fits are frequent without sedatives. They have always been more usual at the time of menstruation. There is no aura and no cry. The head is thrown back, the arms outstretched. The tonic and clonic phases affect the whole body, there is frothing 
at the mouth, the tongue is bitten and she is incontinent of urine. Her eyes turn upwards and the pupils dilate widely. Her colour is remarkably pale throughout. Recovery takes place after about three-quarters of an hour.

Menstruation has always been irregular. The secondary sex characteristics are normal. Pubic and axillary hairs are present, and the breasts are well formed and equal.

\section{Investigations}

Craniometry.-Inner canthus distance 2.9 cms.; Palpebral fissure $3.05 \mathrm{cms}$. Maximum breadth $14: 2 \mathrm{cms}$. Maximum length $17 \cdot 1 \mathrm{cms}$. Cephalic index 83 . Height $13 \cdot 4 \mathrm{cms}$. Circumference 51.9 cms. Capacity 1238 c.cs. The pituitary fossa was reported as being normal. These measurements show the head to be small, but rather tall in proportion to the circumference. There is no indication of hydrocephaly.

Skeleton.-Height 62 ins., Span 64 ins.; Pubis-vertex, 30 ins.; Pubis-feet, 32 ins. These measurements are in accordance with a mild degree of arachnodactyly, both the arms and legs being long in comparison to the trunk.

Temperature.-No hyperthermia over five days, when the temperature was taken four-hourly by the mouth. Hyperthermia has been observed in three of the writer's eleven cases of retinitis pigmentosa and in two cases under R. M. Stewart's care who have mental deficiency, obesity, hypogenitalism, polydactyly, Friedreich's ataxia and retinal abnormalities.

Blood.-R.B.C.s 4,840,000. Haemoglobin 98 per cent. Colour index 1.02. W.B.C.s 11,400. Polymorphs : mature 60.5 per cent.; immature 11.5 per cent. Lymphocytes 15 per cent. Monocytes 4 per cent. Eosinophils 1 per cent. Turk cells 8 per cent. Wassermann and parallel reaction negative. Calcium $10 \cdot 4 \mathrm{mgms}$. per cent. Phosphate 4.12 mgms. per cent. Cholesterol $183 \mathrm{mgms}$. per cent. (All these figures are normal.)

Glucose tolerance curve.

$$
\begin{aligned}
& 0 \text { hrs. } \quad \text {... } 94 \text { mgms. per cent. } \\
& \frac{1}{2} \text { hrs. } \quad \text {... } 104 \text { mgms. per cent. } \\
& 1 \text { hrs. } \quad \text {... } 144 \mathrm{mgms} \text {. per cent. } \\
& 1 \frac{1}{2} \text { hrs. } \quad \ldots \quad 142 \mathrm{mgms} \text {. per cent. } \\
& 2 \text { hrs. } \quad \text {... } 134 \mathrm{mgms} \text {. per cent. }
\end{aligned}
$$

This is normal.

Urine.-Acid.S.G. 1010. No abnormal constituents. No phenyl pyruvic acid. An occasional epithelial cell and some urates in the deposit. Negative for bromide. 
Water-salt metabolism.-After four days feeding on a constant diet of low chloride content.

$\begin{array}{lccc} & & \text { Urine Volume. } & \text { Sodium Chloride. } \\ \text { 5th day } & \ldots & 1180 \text { c.cs. } & 5 \cdot 07 \text { gms. } \\ \text { 6th day } & \ldots & 1110 \text { c.cs. } & 6 \cdot 33 \text { gms. } \\ \text { 7th day } & \ldots & 660 \text { c.cs. } & 6.34 \text { gms. } \\ \text { 8th day } & \ldots & 725 \text { c.cs. } & 7 \cdot 83 \text { gms. }\end{array}$

10 grams of sodium chloride were given on the seventh morning. There is a diminution instead of an increase in the volume of urine secreted after the chloride was given and there is a retention of about 4 grammes of sodium chloride, as normally about eight of the ten grams are excreted within 48 hours in addition to the normal output.

Urine dilution test.

\begin{tabular}{|c|c|c|c|}
\hline Time. & & & Urinary Volume. \\
\hline 7.40 a.m. ... & $\ldots$ & $\ldots$ & 50 c.cs. \\
\hline 8.10 a.m. $\ldots$ & $\ldots$ & $\ldots$ & 110 c.cs. \\
\hline 8.40 a.m. $\ldots$ & $\ldots$ & $\ldots$ & 380 c.cs. \\
\hline 9.10 a.m. $\ldots$ & $\ldots$ & $\ldots$ & 350 c.cs. \\
\hline 9.40 a.m. $\ldots$ & $\ldots$ & $\ldots$ & 270 c.cs. \\
\hline 10.10 a.m. $\ldots$ & $\ldots$ & $\ldots$ & 30 c.cs. \\
\hline 10.40 a.m. $\ldots$ & $\ldots$ & $\ldots$ & 55 c.cs. \\
\hline 11.10 a.m. & $\ldots$ & $\ldots$ & 30 c.cs. \\
\hline
\end{tabular}

1000 c.cs. of water were given between 6 and 6.30 a.m. The volume and rate of secretion are normal but there is a delay in reaching the maximum rate of output compared with controls.

Melanosome-dispersion was not observed by the only specimen of urine tested on a frog.

\section{Discussion}

The case of juvenile amaurotic idiocy described has a characteristic family history. A sister is similarly affected.

There is a mild degree of arachnodactyly and other abnormalities are present which have been described in association with this condition (Marfan, 1938). In particular, there are differences in the size and colour of the nipples and areolae, abnormal heart sounds, laxity of ligaments, a kyphosis and the arms and legs are long compared with the trunk. Five cousins also have long digits.

There is a salt retention of about four grammes compared with controls and a diminution instead of the normal increase in urinary output after the sodium chloride was given. In addition there is a delay in the excretion of the water drunk in the urine dilution test. These results taken in conjunction show a marked abnormality of water-salt metabolism. 


\section{Summary}

A case of juvenile amaurotic idiocy with a mild degree of arachnodactyly is described.

There is abnormality of the water-salt metabolism, shown by a chloride retention and a delayed urinary secretion in response to sodium chloride excretion and urine dilution tests.

I would like to thank Mr. Arnold Sorsby, Mr. A. Harold Levy and Dr. R. M. Stewart for the help that they have given me.

\section{REFERENCES}

Batten, F. E. (1903).-Trans. Ophthal. Soc. U.K., Vol. XXIII, p. 386.

Marfan, A. B. (1938). -Ann. de méd., Vol. XLIV, p. 1.

Velmagen, Jr., K. (1932).-Klin. Monatsbl. f. Augenheilk., Vol. LXXXIX, p. 1.

ZONDEK, H. and KOELER, G. (1932).-Deutsch. med. Wochenschr., Vol. LVJII, p. 2025.

\section{THE MECHANISM OF AQUEOUS SECRETION IN MAMMALIA}

BY

\section{THOMSON HENDERSON}

NOTTINGHAM

IN their recent communication "Some observations on the present position of our knowledge of the intra-ocular fluid" ${ }^{1}$, Duke-Elder and his collaborators make the challenging statement that "there is no conclusive or indeed persuasive evidence that the intra-ocular fluid is a secretion." A theory of function however plausible, particularly one depending on physical properties, is invalid unless it is substantiated by suitable mechanical and structural data. It is exactly on this score that dialysis fails both in its original form as in its latest modification of filtrate-dialysis.

Like all who received their early training in ophthalmology at the beginning of the century, I was brought up on the then current view of Leber, that the aqueous was a filtrate. At an early stage in my research it became manifest that structure and alleged function did not go hand in hand, as the essential mechanism for filtration of aqueous does not exist in the ciliary region ${ }^{2}$. The ciliary body is not a closed region but its areolar tissue is permeated by aqueous and therefore the one and only essential factor for filtration-a difference in hydrostatic level on either side of a passive epithelial membrane-does not exist. The anatomical conditions of the eye being what they are, a dialysate from the ciliary capillaries can not gain admission into the posterior aqueous 